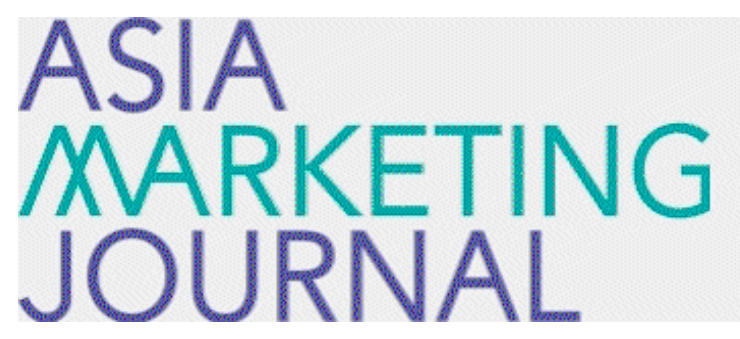

ASIA MARKETING JOURNAL

Volume 3 | Issue 4

Article 5

$12-1-2001$

\title{
서비스 복구접점에서의 고객만족과정에 관한 연구
}

Ho Jung Lee

Follow this and additional works at: https://amj.kma.re.kr/journal

Part of the Marketing Commons

\section{Recommended Citation}

Lee, Ho Jung (2001) "서비스 복구접점에서의 고객만족 과정에 관한 연 구," Asia Marketing Journal: Vol. 3 : Iss. 4 , Article 5.

Available at: https://doi.org/10.53728/2765-6500.1077

This Article is brought to you for free and open access by Asia Marketing Journal. It has been accepted for inclusion in Asia Marketing Journal by an authorized editor of Asia Marketing Journal. 


\title{
서비스 복구접점에서의 고객만족과정에 관한 연구*
}

\section{A Study on the Process of Customer Satisfaction with Service Recovery Encounter}

\author{
이호정(우석대학교 경영학부 겸임교수) \\ lhi-8301@hanmail.net
}

\begin{abstract}
본 연구는 서비스 접점에서 서비스 실패가 일어나는 경우 기업의 복구노력이 고객의 만족에 미치는 영향에 관한 연구이다. 먼저 서비스 실패에 대한 기업의 복구노력이 갖는 의미를 살펴보고, 서비스 복구노력이 고객의 만족과정예 어떻게 영향을 미치는 지에 대하여 항공산업을 연구대상으로 기대불일치이론, 정당성이론 및 귀인이론올 적용하여 다양한 관점에서 실중 분석하였다. 특히 기대불일치이론 및 정당성이론에 관한 선행 연구들을 상세히 고찰하고, 이러한 이론적 관점에서 서비스 실패 후 기업의 복구노력이 고객의 만족과정에 어떻게 영향을 미치는 지를 다중회귀분석 및 구조방정식 모형을 이용하여 실중 분석하였다. 또한 조직행동론의 연구결과를 이용하여 서비스 실패에 대한 귀인적 추론결과가 소비자의 만족과정에 미치는 영향을 검증하였다
\end{abstract}

* 논문접수 : 02.04 게재확정 : 02.06 


\section{1. 서 론}

오늘날 서비스 기업들은 경쟁이 심화되면서 그 어느 때보다도 고객서비스에 대한 강한 압력에 직면하고 있다. 서비스는 본질적 특성상 실패가 불가피하다. 또한 서비스 실패에 대한 기업의 부적절한 대응은 상황을 더욱 악화시켜서 고객을 상실하기도 한다. 하지만 서비스 실패는 고객으로 하여금 문제를 해결하는 상황에 보다 열중하고 주시토록 하기 때문에 서비스 기업에게 기희가 된다(Berry and Parasuraman 1991; Zeithaml, Berry and Parasuraman 1993). 서비스 복구를 잘 수행하는 경우에는 오히려 불만족한 고객을 만족고객으로 전환시킬 수 있으며(Johnston 1995), 효과적인 서비스 복구를 통하여 만족한 고객들은 오히려 처음부터 서비스 복구를 경헙하지 않은 고객들보다도 해당기업에 대해 더욱 만족하고 애호도를 가지며 호의적인 구전활동에 참여한다(Etzel and Silverman 1981). 따라서 서비스 접점에서의 서비스 복구는 고객 만족, 고객 유지, 재애호 및 호의적인 구전 의도 등과 관련해서 매우 중요하다(Hart, Heskett and Sasser 1990; Zeithaml, Berry and Parasuraman 1996).

서비스 실패 및 복구에 관한 연구는 그 중요성에도 불구하고, 연구방법의 한계 및 불평처리 연구에의 흡수 둥으로 상대적으로 관심올 받지 못했으며, 최근 들어 이러한 서비스 실패/복구 정황에 관한 연구가 시도되고 있으나(Smith, Bolton, and Wagner1999; McCollough, Berry, and Yadav 2000), 확립된 연구모형의 개발은 아직 미흡한 상황이다.

소비자 행동을 연구하는데 있어 소비자의 행동을 설명하기 위한 다양한 이론적 모형의 필요성은 서비스 실패/복구 접점에서도 예외가 아니다(Rust and Metters 1996). 본 연구에서는 서비스 실패/복구 정황에 대한 고객의 평가과정 즉 만족과정올 보다 다양한 관점에서 살펴봄으로써 서비스 접점에서의 고객평가과정을 폭 넓게 이해하고자 한다. 즉 기대불일치 이론, 정당성 이론 및 귀인 이론을 서비스 실패/복구 과정에 동시에 접목시킴으로써 서비스 실패/복구정황에 대한 보다 포괄적인 분석을 시도한다.

기대불일치이론은 Oliver(1980)이후 고객의 만족과정을 설명하는 대표적인 이론으로서 확고한 자리를 잡아 왔다. 사실 기대불일치이론은 제품의 구매과정 전반에 대한 만족과정을 설명하는 도구로서의 유용성은 확립되어 있으나, 실패후 복구라는 서비스 접점의 특수한 상황을 설명하는 도구로서의 역할은 거의 연구되어 있지 않다. 하지만 교환적인 거래가 있는 곳에서는 반드시 행위주체의 기대와 행위결과가 따르기 마련이다. 따라서 이미 실패한 서비스라 할지라도 서비스 접점에서 실패를 복구할 가능성이 존재하며, 이에 대해 거래 당사자들은 새로운 거래 즉 복구거래에 대한 기대가 형성되고 또한 이에 대한 평가가 이루어진다. 즉 기대불일치이론은 서비스 실패/복구 정황에서도 적용이 가능할 것이다. 하지만 서비스 복구과정에서의 복구기대에 대한 개념화를 시도하는 정도의 연구(Kelley and Davis 1994)만이 현재 진행되어 있을 뿐이다. 따라서 본 연구에서는 아직 개념이 확립되어 있지 않는 복구기대 개념을 현실적인 관점에서 제시하고, 기대불일치이론의 서비스 실패/복구정황에 대한 적용 가능성을 조사할 것이다. 이는 기대불일치이론의 적용범위를 확장하며 서비스 복구 정황에 대한 보다 면밀한 분석이 가능하게 할 것이다.

한편 사희적 교환이론의 프레임웍이 마케팅에 도입되면서 정당성 이론이 고객만족과정에 대한 설명이론으로서 제시되고 있다. 즉 지각된 정당성 차원인 분배적 정당성, 절차적 정당성 및 상호작용적 정당성이 고객만족의 결정요인으로서 제시되고 있다. 정당성이론은 
그동안 불평처리 문헌에서 불평처리의 결과가 재구매 혹은 구전 등의 구매후 행동적 결과에 영향을 미치는 데 있어서 매개변수로 연구되어왔다(Goodwin and Ross 1992: Blodgett, Hill, and $\operatorname{Tax}$ 1997). 이러한 정당성이론이 서비스 기업의 복구노력에 대한 고객의 평가에 관한 연구에 도입된 것은 비교적 최근의 일이다. 본 연구에서는 정당성이론에 대한 선행 연구들을 고찰하고 세가지 지각된 정당성 차원이 서비스 실패 후 복구만족에 미치는 영향을 실중 분석한다.

한편 Weiner(1980)가 제시한 귀인적 추론차원이 고객의 평가 및 행동적 결과에 미치는 영향에 관한 많은 연구(Folkes 1984; Folkes, Koletsky, and Graham 1987)에도 불구하고, 서비스 실패에 대한 귀인적 추론결과가 서비스 복구과정에서 고객의 복구만족에 어떠한 영향올 미치는 지에 대한 연구는 아직 전무한 실정이다. 본 연구에서는 조직 행동론의 연구결과를 도입하여 귀인적 요인이 서비스 실패/복구정황에서 고객의 만족에 미치는 영향을 부분적이나마 파악하고자 한다. 즉 상황적 요인으로서 서비스 실패에 대한 귀인적 추론결과가 불형평성 지각에 미치는 영향올 규명하고, 이러한 불형평성 지각이 정당성 지각을 통하여 복구만족에 미치는 영향울 확인합으로써 서비스 실패/복구 접점에서의 소비자의 귀인적 추론결과가 고객의 평가에 미치는 영향을 조사한다.

다음 장에서는 서비스 실패 및 기업의 복구노력에 대한 기존 문헌들을 고찰한다. 제3장에서는 서비스 복구노력에 따른 소비자 만족과정에 대하여 기대블일치 이론 및 정당성이론에 관한 선행 연구들을 고찰하고, 연구가설 및 연구모형을 제시한다. 제4장에서는 실중자료률 토대로 연구가설을 검중하고 분석결과를 제시한다. 또한 정당성 접근모형과 기대불일치 접근모형의 분석결과를 비교한다. 끝으로 제 5 장에서는 본 연구의 주요결과와 한계점을 요약하고 연구의 시사점 및 향후 연구에 대한 제언들을 논의한다.

\section{2. 서비스 실패 및 기업의 복구노력에 관한 선행 연구}

\section{1. 서비스 실패의 원인}

서비스 실패가 발생하는 원인은 주로 서비스의 특유한 특성들인 비분리성, 이질성, 무형성 등에 기인한다. 특히 서비스 제공자에 따라(즉 복수제공자의 이질성), 또한 시간과 장소에 따라(단일제공자의 이질성) 서비스 제공자의 행위는 변화하기 매문에 실수가 없는 서비스를 제공하는 것은 불가능하다. 또한 서비스롤 창출하는 과정에 있어서 고객의 관여는 서비스 문제를 야기하는 또 다른 원인이다. 즉 고객은 서비스 과정의 일부이며 변화를 일으킬 수 있는 중요한 요인으로서 서비스 제공 시스템이 서비스 창출과정에서 고객들을 동반하기 때문이다(Lovelock 1991).

\section{2. 서비스 실패에 대한 기업의 복구노력의 의의}

서비스 복구는 서비스 제공자가 서비스 실패에 대한 반웅으로서 갖는 행위들(Grönroos 1988)로서 최초의 서비스 제공에 대한 고객 지각이 고객의 허용영역 이하로 떨어진 결과에 
대해 서비스 제공자가 행하는 것이다(Zeithaml et al. 1993). 서비스 복구는 서비스 품질과 고객 애호의 중요한 결정 요인중 하나이며, 수익성에 직접적인 영향울 미침에도 블구하고 주목반지 못하거나 때로는 완전히 무시되어 왔다(Heskett, Sasser, and Hart 1990). 서비스 복구는 손실 통제 이상으로서 서비스 실패가 발생한 이후의 서비스 과정을 관리하는 데 매우 유익한 도구이다. 따라서 서비스 실패의 효률적인 복구는 전략적으로 기업의 고객지향의 중요한 요소로서 간주되어야 한다(Bell and Zemke 1987). 또한 서비스 복구는 고객으로 하여금 의사소퉁에 참여하고 기업에 대한 그들의 애호도률 강화시키는 기회이다(Berry and Parasuraman 1991). 서비스 복구 역설(paradox of service recovery)에 따르면 복구에 의해 서비스 실패가 만족스럽게 치유된 고객들은 실패를 경헙하지 않은 고객들보다도 그 기업에 대해 더욱 만족하고 더욱 애호하며 그리고 더욱 호의적인 구전할동에 참여한다(Hart et al. 1990). 결론적으로 서비스 복구는 고객 만족의 대안적 봉로로서 장기적으로 고객과의 우호적인 관계로 발전하는데 있어 시금석이며, 불만족한 고객을 만족시키기 위한 기회이다.

\section{3. 서비스 복구노력에 관한 선행연구}

\subsection{1. 서비스 실패의 유형 및 복구전략}

Bitner, Booms, and Tetreault(1990)는 항공, 호텔 그리고 레스토랑산업을 대상으로 서비스 접점에서의 만족/불만족의 원인을 규명하였다. 이들은 세 가지의 실패 형태들 즉 핵심서비스 실패, 명확한 고객펄요 혹은 요청에 대해 적절하게 반웅하는데 있어서의 실패, 부주의하고 불필요한 종업원의 행위들을 규명했다. 이들은 불만족한 서비스 접점 서비스 실패 상황에 반응하는 종업원의 무능력 혹은 무의지에 의해 악화된다고 주장하였다. 또한 이들은 서비스 실패를 성공적으로 관리하는 방법으로 서비스 문제의 인정, 사과, 실패상황에 대한 설명 그리고 유형적 보상을 제시하였다.

Bitner, Booms, and Mohr(1994)은 호텔, 레스토랑 그리고 항공산업을 대상으로 중업원 관점에서 서비스 접점의 고객만족/불만족에 영향을 미치는 사건과 행동을 확인하고 Bitner et al.(1990)의 연구와 비교 평가하였다. 이들은 접점 사건을 서비스 제공시스템 실패에 대한 종업원의 반응, 고객 펄요와 요청에 대한 종업원의 반웅, 독자적이고 불필요한 종업원의 행위 및 문제고객의 행동 등 네 그룹으로 분류하였다. 또한 그들은 중업원들이 고객 불만족의 원인을 자신들의 잘못으로 생각하기보다는 서비스 제공시스템의 실패나 문제 고객의 행동 등 외부의 탓으로 돌리는 경향이 있다는 것을 발견했다. 또한 고객은 서비스 실패의 영향을 완화시키는 정보를 필요로 하며, 사과는 고객에게 서비스 제공자가 관심을 갖고 있으며, 고객의 좌절감 내지 욕구불만을 이해하고 있음을 주지시키는 유용한 도구라고 주장하였다.

Bell and Zemke(1987)는 서비스 기업은 모든 고객들이 복구 기대률 갖고 있다는 사실을 인지하여야 하며, 서비스 복구는 계힉적인 과정이 펄요하다고 제안하였다. 즉 기업은 실패에 대한 적절한 반웅설계가 요구되며, 복구과정은 적절히 복구를 수행할 수 있도록 권한이 부여된 쵝일선의 종업원에 의해 실행되어야 한다고 주장하였다. 이들은 서비스 복구의 요소로서 사과, 신속한 복원, 감정이입, 상징적인 보상 및 후속조치의 다섯 가지를 제시하였으며, 사과가 분노한 고객을 다루는데 있어서 가장 강력한 방법이라고 주장하였다. 
2.3.2. 서비스 복구노력에 대한 고객 평가와 행동적 결과

서비스 복구노력은 불평행동 및 고객만족 둥의 고객평가와 구전 및 재구매 의도 등의 행동적 결과에 영향을 미친다. Gilly(1987)는 오일기업 서비스를 대상으로 한 연구에서 불평처리에 대한 고객지각은 불평해결에 대한 고객의 만족정도에 영향을 미친다는 것을 발견했다. Zeithaml, Parasuraman, and Berry(1990)는 서비스 복구에 만족한 고객들과 만족하지 못한 고객들간의 지각된 서비스 품질에 있어 유의한 차이가 있음을 발견하였다. 또한 Bitner(1990)는 서비스 실패에 있어서 조직화된 서비스 환경과 종업원의 호의적 반웅 즉 설명과 보상제공이 고객이 지각한 서비스 실패의 귀인적 추론과 서비스 접점만족에 영향을 미친다는 것올 발견하였다. Tax and Chandrashekaran(1992)은 레스토랑에 대해 불만족한 경헙을 한 고객의 구매후 행동을 연구하였다. 연구결과 불평처리의 품질 즉 우수한 서비스 복구가 서비스 경헙의 전반적 평가에 긍정적인 영향을 준다는 것을 발견하였다. Spreng, Harrel, and Mackoy(1995)는 초기에 제공된 서비스 수행의 속성들이 전반적인 고객만족에 중요한 영향올 미치기는 하나, 서비스 복구에 대한 고객만족이 전반적인 고객만족의 가장 중요한 전제라고 제안하였다.

\section{3. 서비스 복구노력에 따른 고객의 만족과정}

\section{1. 고객만족과정에 대한 정당성 이론}

\subsection{1. 정당성 이론}

정당성이론은 여러 갈둥상황에 대한 개인들의 반웅들을 설명하기 위해 널리 연구되어왔으며, 구매자/판매자간의 거래에도 적용되어 왔다. 연구에 따르면 정당성(justice)의 개별적 구체화인 공평성(fairness)은 만족, 애호도 등의 심리적 결과 및 이직, 재구매 의도 등의 행동적 결과에 영향을 미친다. 사회적 교환이론은 사람들이 교환을 평가하는 데 있어서 영향을 미치는 정당성의 3 가지 차원을 규명했다. 이는 자원 배분과 교환에 대한 지각적 결과인 분배적 정당성(Adams 1965), 의사결정이 이루어지고 갈둥이 해결되는 수단인 절차적 정당성(Thibaut and Walker 1975), 그리고 정보가 교환되고, 결과들이 전달되는 방법인 상호작용적 정당성(Bies and Moag 1986)으로 이루어져 있다. 한편 Clemmer and Schneider(1996)는 고객이 3가지 차원에 대하여 서비스 접점을 평가한다고 결론 내렸다. 첫째 결과차원인 접점의 결과로서 고객들이 받는 효익(혹은 그것의 부족), 둘째 과정차원인 접점을 지도하는 조직의 정책과 방법들, 셋째 상호작용차원인 접점동안 개인 상호적 대우와 커뮤니케이션의 품질이 그것이다. 이러한 세 차원은 지각된 정당성의 차원과 그대로 대응이 된다.

\section{(1) 분배적 정당성}

분배적 정당성은 둘 이상의 당사자사이의 논쟁, 교섭 혹은 의사결정의 유형적 결과에 대한 지각된 공평성이다(Deutsch 1975). 즉 개인이 지각하는 분배적 정당성은 분배에 대해 갖는 예상이 어느 정도 충족되는가에 달려있다. 분배적 정당성의 개념은 각 당사자가 그 교환에 기여한 바에 비례하여 결과를 받아야 된다는 형평성, 개인의 필요성의 정도에 따라 
결과를 받아야 된다는 필요성 및 기여도에 관계없이 모든 당사자가 동일한 결과룰 받아야 된다는 평둥성으로 구성된다. 그러나 교환이론에서의 형평성의 기준성(anchoring) 때문에 마케팅분야의 연구는 분배적정당성의. 내용으로서 형평성에 거의 독점적으로 관심이 두어졌다.

분배적정당성은 고객의 불평처리에 대한 평가(Blodgett, Granbois and Walters 1993; Tax, Brown, and Chandrashekaran 1998) 및 서비스 접점의 서비스 실패와 복구에 대한 만족 및 행동적 결과에 영향을 미친다고 알려져 있다(Smith et al. 1999; McCollough et al. 2000), 따라서 다음과 같은 가설을 세운다.

가설1 : 분배적 정당성에 대한 고객지각은 서비스 접점에서의 복구만족에 긍정적인 영향을 미칠 것이다.

(2) 절차적 정당성

절차적 정당성은 논쟁 혹은 교섭의 결과에 이르는데 의사결정자에 의해 사용되어지는 정책, 절차 그리고. 기준에 대한 지각된 공평성이다(Thibaut and Walker 1975). 분배적 정당성과는 대조적으로 절차적 정당성은 결과의 분배에 대해 의사결정이 도출되는 과정 혹은 방식에 대한 지각된 공평성을 의미한다.

절차적 정당성의 내용으로 과정통제, 결정 통제, 접근성, 적시성, 처리속도 및 유연성이 제시되고 있다(Gilly 1987; Gilly and Gelb 1982; Tax et al. 1998). 과정통제란 의사결정과정에서의 의사소통의 자유로서 쉽게 불평할 수 있는 접근성을, 결정통제는 결정결과를 받아들이거나 거절할 수 있는 자유로서 기업의 결정에 대한 불복의 자유를 의미한다 접근성은 절차에 착수하는데 있어 용이성을, 적시성은 문제에 대한 기업의 반웅속도률, 처리속도는 문제를 해결하는 데 걸리는 시간올, 유연성은 개별적인 상황을 반영하는데 있어 절차의 적웅성올 의미한다. Clemmer(1993)는 서비스 접점에 관한 연구에서 유연성, 대기시간/반웅성 그리고 효율성을 절차적 정당성의 차원으로 규명했다.

절차적 정당성은 고객의 불평처리 평가(Goodwin and Ross 1992; Blodgett et al.1997; Tax et al. 1998) 및 서비스 실패후 복구에 따른 만족 및 행동적 결과에 영향을 미치는 것으로 밝혀졌다(Smith et al. 1999; McCollough et al. 2000). 따라서 다음과 같은 가설을 세운다.

가설2 : 절차적 정당성에 대한 고객 지각은 서비스 접점에서의 복구만족에 긍정적인 영향을 미칠 것이다.

(3) 상호작용적 정당성

상호작용적 정당성은 사랍들이 갈등 해결과정 중에 대우받는 방식이다(Bies and Moag 1986). 이 개념은 절차적 정당성의 하위개념으로 출발하였으며, 교환 상대방과의 관계에 있어서 고객의 관점을 받아들이는 것으로서 사람들간의 의사소통에서의 공평성울 의미한다. 특히 사람들이 적절한 문제해결절차나 적당한 크기의 보상을 받음에도 불구하고 불공평하게 취급되는 것에 대한 설명을 제공한다(Bies and Moag 1986; Bies and Shapiro 1987). 상호작용적정당성의 내용으로는 진실성, 설명의 제공(Bies and Moag 1986), 친절함, 친근함, 민감성, 관심, 정직성(Clemmer 1993), 노력(Mohr 1991) 및 정중함과 신뢰성(David 1998)이 제시되고 있다. 
기존연구에 따르면 소비자 블평상황에서 비난의 수용(Goodwin and Ross 1992)과 사과의 제공(Bies and Shapiro 1987; Folkes 1984)이 중요한 요소라고 제안하고 있으며, 불평의 해결에 있어서 커뮤니케이션의 중요성 때문에 상호작용적 정당성의 개념은 톡히 소비자의 불평후 행동을 이해하는 데 적절하다고 한다. 또한 공평한 개인 상호간 대우는 서비스 접점에서의 만족(Bitner et al. 1990), 불평처리에 대한 더 나은 전반적인 평가(Goodwin and Ross 1992) 그리고 호의적인 재구매 의도(Blodgett and Tax 1993)에 기여한다. 따라서 다음과 같은 가설을 세운다.

가설3 : 상호작용적 정당성에 대한 고객지각은 서비스 접점에서의 복구만족에 긍정적인 영향을 미칠 것이다.

3.1.2. 서비스 실패에 대한 귀인적 추론결과의 정당성 지각에 대한 효과

서비스 실패에 대한 귀인적 추론결과가 서비스 복구노력과 지각된 정당성 사이의 관계에 영향을 미칠 것으로 기대된다. Utne and Kidd(1980) 및 Greenberg and Omstein(1983)는 조직행동분야에서의 불형평성 지각에 대해 상황적 요인이 중요한 영향을 미친다고 주장하였다. 이들은 불형평성의 지각에 있어서 귀인과정의 역할을 강조하면서 귀인이론이 형평성이론의 예측에 도움을 줄 수 있음을 시사하고 있다. 특히 Utne and Kidd(1980)는 불형평성에 의해 유발된 긴장의 정도를 결정하는데 인과적 귀인이 매우 중요하다고 주장하였다. 그들은 불형평성에 대한 원인의 위치, 안정성 및 고의성 여부가 긴장의 정도 및 긴장의 해소반웅의 정도에 영향을 줄 수 있는 중요한 정보라고 주장하였다. 즉 이들은 불형평성 지각이 내부적으로 유발되어지거나, 안정적인 것으로 생각되어지거나 혹은 의도적인 것으로 생각되어지는 상황에서 불형평성에 의한 긴장의 정도가 더욱 크다고 지적했다.

교환주의적 관점의 이 이론은 마케텅 상황에도 적용이 가능하다. 즉 거래가 고객의 기대에 미치지 못함으로써 서비스 실패가 발생하는 경우에는 이러한 교환관계는 형평성을 상실하게 되고 따라서 고객은 당해 교환에 있어서 불형평성을 지각하게 된다. 그런데 형평성 지각에 대한 상황적 접근이론에 따르면 동일한 서비스 실패에 대하여도 귀인적 추론 결과에 따라 고객의 불형평성 지각정도는 다률 것이다. 즉 실패의 원인이 회사에 있고, 실패가 반복될 가능성이 크며, 희사가 사전에 예방할 수 있었던 서비스 실패의 경우에는 그렇지 않는 경우보다 뷸형평성 지각의 정도가 클 것이다. 따라서 다음과 같은 가설을 세운다.

가설4 : 서비스 실패에 대한 원인의 위치, 원인의 안정성 및 통제가능성에 대한 추론결과에 따라 불형평성의 지각수준이 다를 것이다.

가설4-1 : 서비스 실패에 대한 원인의 위치가 고객보다는 서비스 제공자에게 있다고 추론될수록 불형평성의 지각정도가 클 것이다.

가설4-2 : 서비스 실패에 대한 원인이 안정적인 것으로 추론될수록 블형평성의 지각정도가 클 것이다.

가설4-3 : 서비스 실패에 대한 원인이 서비스 제공자가 퉁제가능한 것으로 추론될수록 불형평성의 지각정도가 클 것이다. 
한편 서비스 복구노력은 이러한 불형평성을 해소함으로써 서비스 접점에서 고객의 만족을 유도하는 과정이다. 또한 동일한 서비스 복구노력이라 할지라도 서비스 복구노력으로 인한 정당성 지각의 정도는 서비스 실패에 대한 퀴인적 추론결과에 따라 다를 것이다. 즉 귀인적 추론의 유형에 따라 불형평성 지각의 차이가 발생할 것이기 매문이다. 형평성은 분배적 정당성올 판단하는데 있어 보편적으로 사용되는 분배규칙으로서 불형평성의 지각은 분배적 정당성 지각에 부정적으로 영향을 미칠 것이다. 따라서 서비스 실패에 따른 귀인적 추론결과는 불형평성 지각의 정도에 영향올 미쳐, 분배적 정당성에 대한 지각올 통하여 서비스 접점에서의 복구만족에 간접적으로 영향올 미칠 것으로 예상된다. 따라서 다음과 같은 가설을 세운다.

가설5: 서비스 실패의 귀인적 추론으로 인한 불형평성의 지각정도가 클수록 희사의 서비스 복구성과에 따른 분배적 정당성 지각의 정도에 부정적인 영향을 미칠 것이다.

\section{2. 고객만족과정에 대한 기대불일치 이론}

\subsection{1. 기대불일치이론}

Oliver(1980)에 따르면 일반적으로 소비자는 구매이전에 제품성과에 대한 기대를 형성하고, 제품 구매 및 사용울 통하여 경헙한 실제의 제품성과를 자신의 기대수준과 비교한다. 실제성과가 사전에 기대했던 것보다 크면 긍정적 불일치로서 소비자는 만족하게 되고, 실제성과가 사전에 기대했던 것보다 작으면 부정적 불일치로서. 불만족하게 된다. 즉 제품 성과가 기대와 일치하는 정도에 따라 제품/서비스에 대한 소비자의 만족 흑은 불만족이 형성된다고 한다. 또한 불일치가 만족에 영향을 미치는 것과 독립적으로 기대도 만족에 직접적으로 영향을 미치며, 따라서 기대와 불일치가 만족에 대하여 부가적 효과를 갖는다고 주장하였다. 이후 Oliver와 DeSarbo(1988)는 불일치 및 기대 외에 성과도 만족판단에 직접적인 영향을 미친다고 주장하였다. 이렇듯 기대불일치이론은 기대, 성과, 불일치 및 만족개념으로 구성되어 있다. 이러한 개념들간의 관계를 자세히 살펴보면 다음과 같다.

\section{(1) 기대}

구매전 기대는 제품의 실제 성과를 평가하기 위한 기준이다. 즉 소비자둘이 제품의 구매 전에 실현될 것으로 예상하는 제품성과에 대한 예측이다(Churchill and Suprenant 1982). 이는 성과가 어떻게 될 것인지를 반영하는 평균적인 제품성과이며(Tse and Wilton 1988), 과거 경험, 구전 커뮤니케이션을 통한 타인의 경험 및 희사에 의해 이루어지는 명시적이고 묵시적인 약속들에 기초한다(Zeithaml et al. 1993).

기대는 성과에 대한 지각 및 불일치에 영향을 미쳐 고객만족에 대해 간접적인 효과를 가지며 또한 만족에 대하여 직접효과를 가지는 것으로 가정된다. 하지만 실중연구는 상당히 혼재된 결과를 보여준다. 즉 기대가 제품성과 평가에 미치는 영향에 대하여 Olshavsky and Miller(1972)는 기대가 제품성과 지각에 긍정적 영향을 미친다고 주장한 반면에, Anderson (1973)은 제품성과 평가에 대한 기대의 효과는 제품에 따라 다르다고 주장하는 등 일치된 견해를 보이지 못하고 있다. 기대가 만족에 대하여 직접적인 효과를 갖는가에 관해서도 이를 지지하는 연구(Oliver and DeSarbo 1988)와 부인하는 연구(Westbrook 1987)가 혼재되어 
있다.

(2) 지각된 성과

지각된 성과란 소비자들이 제품구매 혹은 사용 후에 느끼는 주관적인 제품 성과이다(곽동성과 김규동 1997). 지각된 성과는 직접적으로 만족에 영향을 미치며, 다른 한편으로 불일치를 감소시키는 요인으로 작용하여 간접적으로 만족에 영향을 미치는 것으로 가정된다. 사실 기대불일치이론을 확립한 Oliver(1980)는 기대와 불일치가 가법적으로 만족에 영향을 미치며, 지각된 성과의 만족에 대한 직접적인 효과는 인정하지 않았다. 하지만 많은 연구들에서 지각된 성과가 만족에 직접적인 영향을 미친다는 실증연구들이 제시되었다(Oliver and DeSarbo 1988; Tse and Wilton 1988). 특히 Oliver and DeSarbo(1988)는 기대, 지각된 성과, 불일치, 형평성 및 귀인이 만족판단에 미치는 영향을 실중분석한 결과 지각된 성과가 불일치 다옴으로 중요한 요인이라는 것올 발견했다. 또한 Tse and Wilton(1988)은 소비자 만족판단에 지각된 성과가 기대보다 중요하다고 제안하면서 만족에 대한 지각된 성과의 직접효과를 강력하게 주장하였다. 이후의 연구결과들은 대체로 지각된 성과가 유의적으로 만족에 직접적인 영향을 미치는 것으로 나타났다(곽동성과 김규동 1997; Anderson and Sullivan 1993).

\section{(3) 불일치}

기대불일치이론의 본질적 성격상 구매이전의 제품성과에 대한 사전 기대와 제품 구매 및 사용을 퉁한 지각된 성과사이의 차이에 대한 평가인 불일치는 만족에 직접적인 영향을 미치는 것으로 가정된다. 실중적으로도 대부분의 연구가 불일치가 만족에 영향을 미치는 것으로 나타넜다(Oliver 1980; Oliver and DeSarbo 1988 ). 톡히 Oliver and DeSarbo(1988)는 여러 만족 결정요인중 불일치가 가장 큰 효과를 가진다는 것을 발견하였다. 한편 Churchill and Surprenant(1982)는 내구재에 있어서 불일치가 만족판단에 영향을 미치지 못하며 단지 지각된 성과만이 만족판단에 영향을 미친다고 주장하였다. 하지만 제품의 성과에 대한 사전 기대와 실제 지각된 성과의 비교는 필연적으로 블일치률 가져오며, 또한 동화효과 및 대조효과의 관점에서 불일치는 고객의 만족과정에 있어서 매우 중요한 개념이라고 할 수 있다.

3.2.2. 서비스 실패/복구 정황에 기대불일치이론의 적용

서비스 실패 후 고객은 그러한 실패에 대하여 불평행동 둥의 적극적인 반응이나 혹온 침묵 등의 소극적인 반웅을 보이면서, 실패한 서비스가 복구되기를 기대한다. 이렇둣 서비스 제공자에 의해 복구될 것이라는 기대가 복구기대라 할 수 있다. 또한 이러한 서비스 복구기대에 부응하여 혹은 서비스 기대와는 무관하게 서비스 제공자는 고객의 불만해소롤 위해 서비스 복구노력을 하게 될 것이다. 졀과적으로 서비스 실패 후 고객이 갖는 서비스에 대한 복구기대가 서비스 제공자의 복구노력에 의한 지각된 복구 성과와 비교되고, 그 불일치 정도 여부에 따라 고객은 서비스 접점을 평가할 것이다. 따라서 기대불일치 개념 및 그 과정은 서비스 접점의 서비스 실패/복구 정황에서도 복구기대와 복구성과 그리고 복구 불일치의 개념으로 대체되어 그대로 적용이 가능할 것이다.

Kelley and Davis(1994)는 고객의 복구와 관련된 기대는 서비스 품질차원과는 구별되어야 한다고 주장하면서 서비스 복구에 대한 고객의 기대는 서비스 실패가 발생할 때 서비스 
제공자가 얼마나 효과적으로 서비스 실패를 해결할 것인가에 대한 고객의 지각으로 구성된다고 제안하였다. 이들은 서비스 복구기대가 고객의 사전 서비스 경헙(특히 이전의 복구노력), 구전 커뮤니케이션을 통한 타인의 경험, 그리고 기업에 의해 주어지는 명시적 및 암시적 서비스 약속들에 기초한다고 한다. 또한 서비스 실패경험은 이에 상응하는 서비스 복구와 관련된 후속의 예측적 기대에 영향을 미칠 것이라고 주장하였다.

한편 McCollough et al.(2000)는 서비스 실패/복구 정황에 대한 고객만족과정에 복구불일치 개념을 도입하였다. 복구불일치는 복구기대와 지각된 복구성과 사이의 불일치이다. 이들은 복구기대가 복구성과가 판단되는 표준이며, 복구만족은 복구 기대와 지각된 복구 성과 및 복구 불일치의 함수라고 주장하였다. 이돌에 따르면 서비스 접점만족은 복구노력의 성과가 복구기대를 충족시키거나 초과할 때 이루어지며, 복구성과가 복구기대에 미치지 못할 때는 서비스 제공자의 복구노력에 대하여 만족하지 못한다는 것이다. 결국 기대불일치 모형에서 성과, 기대 및 불일치가 고객만족에 영향을 갖는 메카니즘이 서비스 복구정황에서도 동일하게 적용될 수 있다고 제안하였다.

본 연구에서도 기대불일치 모형에 대하여 실중연구 결과가 혼재되어 있고 또한 복구기대, 지각된 복구성과 및 복구불일치에 대한 개념이 아직 명확하게 확립되어 있지 않온 상황에서 이러한 개념들의 타당성을 검증하고 서비스 접점에 기대불일치이론의 적용가능성을 규명하고자 한다.

서비스 복구기대는 복구불일치에 부정적으로 영향을 미치며, 또한 복구기대는 선택적 지각 및 적응수준이론에 따라 복구만족에 긍정적 영향올 미칠 것으로 기대된다. 또한 지각된 복구성과는 복구불일치에 긍정적인 영향을 미칠 것이며, 또한 복구만족에도 직접적인 영향을 미칠 것이다. 그리고 서비스 복구기대와 지각된 복구성과에 의해 결정되는 복구불일치는 서비스 복구만족 수준에 긍정적인 영향을 미칠 것으로 기대된다. 다만 복구기대가 지각된 복구성과에 미치는 영향은 동화효과 및 대조효과가 동시에 존재할 가능성이 있기 때문에 본 연구에서는 배제한다. 따라서 다음과 같은 가설을 세운다.

가설6: 서비스 복구기대는 복구 불일치의 지각수준에 부정적으로 영향을 미칠 것이다.

가설7: 서비스 복구기대는 서비스 복구에 대한 만족수준에 긍정적으로 영향을 미칠 것이다. 가설8: 서비스 복구에 대한 지각된 성과수준은 복구 불일치의 지각수준에 긍정적으로 영향 을 미칠 것이다.

가설9 : 서비스 복구에 대한 지각된 성과수준은 서비스 복구에 대한 만족수준에 긍정적으로 영향을 미칠 것이다.

가설10 : 서비스 복구기대와 지각된 복구성과간의 불일치는 서비스 복구에 대한 만족수준에 긍정적으로 영향을 미칠 것이다. 


\section{3. 연구모형}

3.3.1. 서비스 접점만족에 대한 정당성 접근모형(그립1)

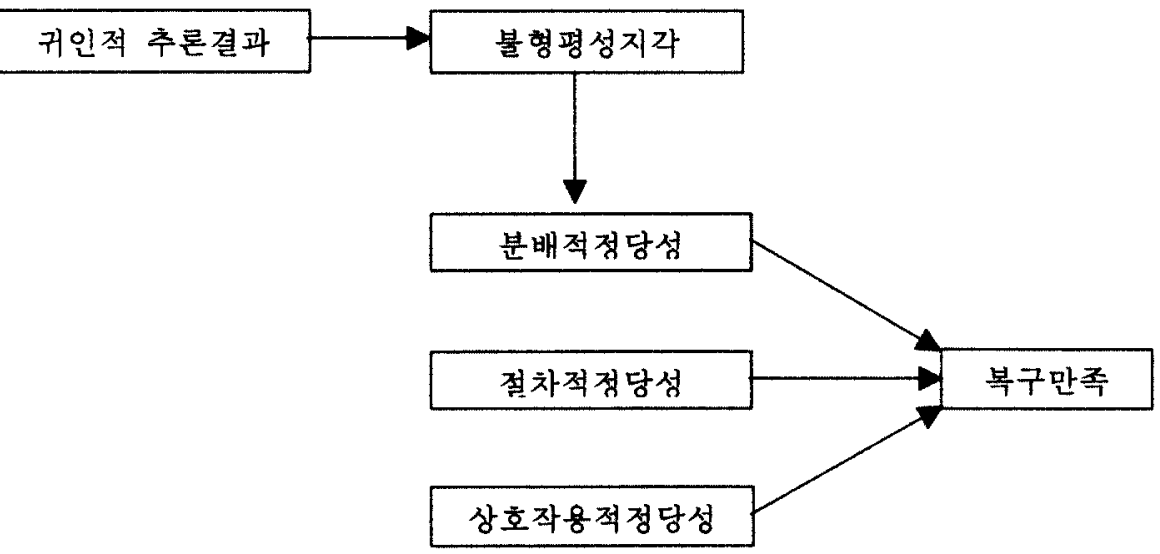

3.3.2. 서비스 접점만족에 대한 기대불일치 접근모형(그림2)

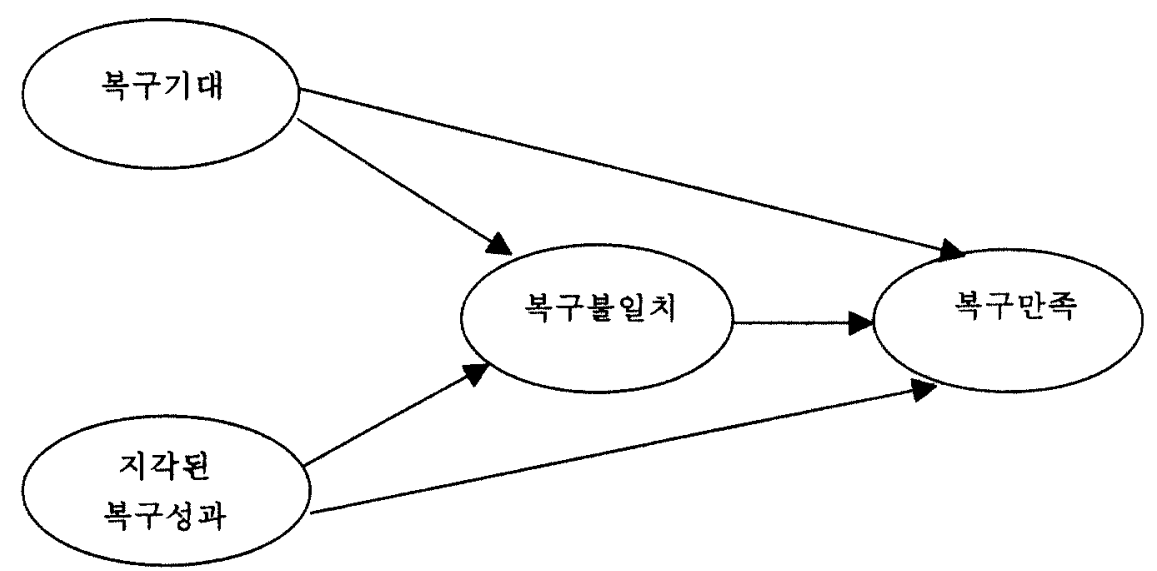

\section{4. 실중 분석}

\section{1. 연구 설계}

\subsection{1. 개관}

본 연구는 서비스 실패이후 기업의 복구노력에 대한 고객의 지각을 연구하는 데 있어 통제된 실험적 환경의 설정 어려움으로 가상적 시나리오에 바탕을 둔 유사실험설계에 
근거하여 수행됐다. 본 연구에서는 항공여행 서비스를 연구환경으로 선택하였으며, 이는 세계화의 진전 및 업무, 관광 및 학업목적 둥의 국제여행이 보편화되어 있기 때문이다. 그리고 항공여행이 실패가 일반적으로 발생하는 서비스산업 중의 하나(Andreeva 1998)로서 항공 여행에 있어 서비스 실패 및 항공사 복구노력에 기인하는 복구기대, 복구 성과 및 정당성에 관한 조작들이 현실적이며, 신뢰할 수 있을 것이라고 예측되었기 때문이다.

본 연구는 연구가설울 검증하기 위하여 2 개의 실헙을 실시하였다. 실험 1 은 복구 기대와 복구성과를 조작하는 것에 의해 기대불일치이론에 의한 만족가설을 서비스 실패/복구 정황에 적용하여 평가하였으며, 실헙 2 는 분배적 정당성, 절차적 정당성 및 상호작용적 정당성의 조작에 의하여 회사의 복구노력에 대한 정당성 지각이 복구만족에 미치는 영향들을 평가했다. 또한 실헙2에서는 귀인적 상황을 조작하여 불형평성 지각에 대한 귀인적 추론결과와 관련되는 가설들을 평가하였다.

본 연구의 초기목적은 서비스 복구접점에 있어서 고객의 복구만족에 대한 기대불일치적 설명과 정당성 접근법에 의한 설명을 동시적으로 관찰하고 이룰 단일 모형화하는 데 있었다. 하지만 이러한 통합적 연구는 실헙적 조작이 불가능하고 분석과정이 복잡해져 실협을 2 개로 분리하여 개별적으로 분석하고 이를 비교하기로 하였다.

\subsection{2. 자료 수집}

(1) 시나리오 작성

실험 1 은 서비스 접점에서의 서비스 실패에 따른 서비스 복구노력이 서비스 접점만족에 미치는 영향을 기대불일치 모형울 적용하여 평가하였다. 이에 따라 설문지를 복구기대의 높고 낮음, 복구성과의 높고 낮음에 따라 $4(2 * 2)$ 개로 조작하였다. 복구기대는 항공기 지연출발에 대하여 비행기 티켓상의 보상규정( 20 만원의 항공 할인권)을 인지하였는가 혹은 그렇지 못했는가(즉 법률상의 한계규정을 인지하였는가)에 따라 높고 낮음으로 조작하였다. 복구성과에 대하여는 다양한 측면에서 조작하였다. 높은 복구성과 조작의 경우에는 지연출발에 대한 보상으로서 항공권 할인권 지급 둥으로 보상의 크기를 크게 하고, 적시적인 직원의 반웅속도 등 절차상 반옹의 신속성, 공감적 사과, 친절한 태도 및 복구노력의 자발성으로, 낮은 복구성과 조작의 경우에는 항공권 할인권을 지급하지 않아 보상의 크기가 작고, 적시적이지 못한 직원의 반웅속도 둥의 절차상 반웅의 지체, 형식적 사과, 불손한 태도 및 복구노력의 비자발성으로 조작하였다.

실험2에서는 피험자들을 분배적 정당성, 절차적 정당성 및 상호작용적 정당성의 3 가지 차원별로 높옴과 낮음으로 구분하고 또한 서비스 실패원인에 대한 통제가능성 여부에 따라 16 개 $(2 * 2 * 2 * 2)$ 의 집단으로 구분 조작하여 정당성 지각이 만족에 미치는 영향 및 서비스 실패에 대한 귀인적 추론결과가 정당성 지각에 미치는 영향에 관해 조사하였다. 즉 분배적 정당성은 보상의 크기 즉 20 만원 상당의 항공할인권올 지급하였는지 아닌지에 따라 높고 낮음으로, 절차적 정당성은 적시적인 직원의 반옹속도 둥 절차상 반웅의 신속성의 높고 낮음에 따라, 그리고 상호작용적 정당성은 사과의 진실성 여부, 태도의 공손성 여부 및 복구노력의 자발성 여부에 따라 높고 낮음으로 구분 조작하였다. 또한 서비스 실패에 대한 통제가능성 여부는 지연출발의 원인을 수리미홉에 따른 항공기 고장 및 경유지 공항사정으로 구분 조작하였으며, 원인의 위치에 대하여는 가상적으로 조건에 맞는 경쟁항공사를 기체가 노후화하고 서비스가 미홉하지만 항공요금이 저렴(10만원)한 경우와 그 반대의 경우룰 상정하여 웅답자가 저렴한 항공편울 이용하도록 합으로써 내적 귀인의 
가능성을 포함시켰으며, 원인의 안정성 여부는 웅답자의 주관적 지각에 맡기기로 하였다

(2) 설문 수집

본 연구는 $\mathrm{S}$ 지역, $\mathrm{C}$ 지역 및 또 다른 $\mathrm{C}$ 지역의 항공여행 경함이 있는 기업체 직원, 교원, 경영대학원생 등을 피험자로 하여 각 시나리오별로 30 부씩 충600부의 설문지를 배포하여, 386 부를 수거하였다(회수을 $64.3 \%$ ). 수거된 설문지중 설문내용예 성실하게 응하지 않은 47 부를 제외한 339 부를 분석대상으로 하였다. 분석대상으로 한 설문지중 실험1과 관련된 설문지는 146 부이며, 실험2와 관련된 설문지는 193 부이다.

분석에 사용된 조사웅답자의 인구통계적 특성의 결과는 다음과 같다. 성별은 여성이 $34.8 \%$ 인 118 명이고, 남성이 $65.2 \%$ 인 221 명으로 나타넜다. 연령은 30 대가 171 명으로 웅답자의 $50.4 \%$ 를 차지하였고, 40 대가 $23.0 \%, 20$ 대가 $23.0 \%$ 이었다. 학력에 있어서는 대졸이상이 $93.2 \%$ 인 316 명이었고 고졸이하는 $6.8 \%$ 인 23 명에 불과하였다. 한편 항공기 이용경험은 5 회이상이 $60.6 \%$ (205명)로서 다수를 차지하고 있으며, 항공기 이용 무경험자는 단지 $8.3 \%(28$ 명 $)$ 에 불과하였다. 항공기 이용 경험 등 표본의 인구통계학적인 특성올 살펴볼 때, 웅답자들은 항공 서비스의 주요고객으로 볼 수 있으며, 잠재고객 가능성까지 고려해 볼 때 표본구성에는 무리가 없는 것으로 판단되었다.

\subsection{3. 변수의 측정}

(1) 복구만족

복구만족은 서비스 복구이후 거래별 판단으로서의 만족을 의미하며, 복구만족에 관한 척도는 3 문항으로 구성하였다. 서비스 경헙이 고객의 욕구를 얼마나 잘 충족시켰는가를 측정한 Westbrook(1980)의 척도(아주 미홉한/아주 충분한), 만족/불만족을 양극으로 다룬 구성개념으로 하는 Oliver and Bearden(1985)의 척도 및 Oliver and Bearden(1985)의 단일차원 척도를 시나리오의 내용 및 현실에 맞게 수정하여 사용하였다. 모두 7점척도를 사용하였다.

(2) 복구기대, 지각된 복구성과 및 복구불일치

복구기대는 서비스 제공자가 서비스 실패가 발생할 때 얼마나 효과적으로 서비스 실패를 해결할 것인가에 대한 고객의 지각이며(Kelly and Davis 1994), McCollough et al.(2000)이 사용한 척도를 본 연구목적 및 한국적 현실에 맞게 수정하여 4문항으로 구성하였다. 또한 지각된 복구 성과 및 지각된 불일치의 정도에 관한 척도는 기존의 기대불일치에 관한 연구(Swan and Trawick 1981; Oliver and Swan 1989a,b) 및 McCollough et al.(2000)에서 사용한 척도를 시나리오 내용 및 한국적 현실에 맞춰 수정하여 각각 6문항 및 3 문항으로 구성하였다. 이러한 3가지 척도 모두 7점척도(아주 그렇지 않다/보퉁이다/매우 그렇다)를 사용하였다.

\section{(3) 지각된 정당성}

분배적 정당성은 Oliver and $\operatorname{Swan}(1989 \mathrm{a}, \mathrm{b}), \operatorname{Tax}(1993)$ 및 Blodgett et al.(1997)이 사용한 척도를 형평성 규칙 관련 3 문항 및 필요성 규칙 관련 1 문항 등 4 문항으로 본 연구에 맞춰 수정하여 사용하였다. 절차적 정당성은 Thibaut and Walker(1975)의 절차적 정당성에 대한 정의에 입각하여 신속성, 절차의 타당성, 접근성, 과정통제를 반영하는 의견의 제시가능성 및 결정통제를 함축하는 의견의 반영성에 관한 척도를 연구 상황에 맞춰 6개의 문항으로 측정하였으며, 상호작용적 정당성은 Blodgett et al.(1997), Tax et al.(1998) 등의 기존 연구들을 
종합하여 문제해결에의 노력정도, 정중함, 신뢰성, 관심을 나타내는 공감 및 의사소통의 적절성 등 5 개 문항으로 연구 목적에 맞춰 이를 측정하였다. 지각된 정당성에 관한 모든 척도는 7점 척도로서 그 기준점은 전혀그렇지않다/보퉁이다/매우그렇다로 하였다.

(4) 거인유형 및 불형평성 지각정도

서비스 실패에 대한 원인의 위치는 내적 귀인과 의적 귀인을 양끝으로 하는 7점 척도 문항 및 단정적 응답문항 등 2 개 문항으로 측정하였다. 원인의 안정성 및 원인에 대한 통제가능성은 Folkes(1984)의 척도를 참고하여 본 연구에 맞게 각각 2개 문항으로 측정하였다. 귀인에 관한 측정척도들은 모두 7점척도를 사용하였다. 불형평성 지각정도는 Oliver and Swan(1989a,b)의 형평성 측정척도를 본 연구에 맞게 수정하고 옹답의 왜곡성(skewness)을 방지하기 위해 10점척도의 3 개 융답문항으로 이률 측정하였다.

\section{2. 분석 및 결과}

\subsection{1. 변수의 신뢰성 및 타당성}

(1) 신뢰성

신뢰성은 내적 일관성에 의한 축정방법으로서 Cronbach의 $\alpha$ 에 의하여 측정하였다. 측정 결과 모든 $\alpha$ 값이 0.68 이상으로 나타나 비교적 높은 내적 일관성을 보였다(Nunnally 1978).

\section{(2) 타당성}

각 문항들의 구성개념에 대한 집중타당성을 검증하기 위하여 SPSS10.0에 의한 탐색적 요인분석올 실시하였다. 이러한 탐색적 요인분석에 따라 비유의적인 문항은 제거하고 분석에 사용하였다. 먼저 실험1에서는 복구기대에 대한 측정문항 2 개, 지각된 복구성과의 측정문항 3 개를 제거하였으며, 복구불일치 및 복구만족에 대한 측정문항중 1 개씩 제거하여, 각각의 구성개념에 대하여 2 개의 측정문항들을 분석에 사용하였다. 정제된 각 구성개념들에 대하여 측정문항들은 0.4 이상의 적재량으로써 유의적인 결과를 보였다(임종원 1997). 다만 지각된 복구성과와 복구만족 개념이 동일한 요인에 적재되었는데 이는 양 구성개념들간의 상관관계가 매우 높기 때문에 나온 결과라고 추측되었다. 하지만 양 구성개념들은 이론적으로 명확히 구분되는 개념으로서 판별타당성 분석올 통해 이러한 구성개념들올 분석에 사용할 지 여부를 검토하기로 하였다.

한편 실험2에서는 분배적정당성에 대한 2 개, 절차적 정당성에 대한 3 개 및 상호작용적 정당성에 대한 2 개의 측정문항을 제거하고 분석에 사용하였다. 각 구성개념들에 대하여 측정변수들은 모두 0.66 이상의 적재량을 나타냄으로써 매우 유의적인 결과를 나타냈다(임종원 1997). 각 실험의 측정변수들의 신뢰성 및 집중타당성 분석결과는 다음 표에 요약되어있다. 
<표1> 신뢰성 검중결과

\begin{tabular}{|c|c|c|c|}
\hline 구성개념 & 변수 & 항목수 & $\alpha$ 계수 \\
\hline \multirow{2}{*}{ 귀인적 지각졀과 } & 풍제가능성 & 2 & 0.88 \\
\cline { 2 - 4 } & 안정성 & 2 & 0.89 \\
\hline \multirow{2}{*}{ 블형평성 } & 블형평성 & 3 & 0.72 \\
\hline \multirow{3}{*}{ 지각된 정당성 } & 분배적정당성 & 2 & 0.73 \\
\cline { 2 - 4 } & 절차적정당성 & 3 & 0.81 \\
\cline { 2 - 4 } & 상호작용적정 당성 & 3 & 0.91 \\
\hline 기대 & 복구기대 & 2 & 0.76 \\
\hline 성과 & 복구성과 & 2 & 0.96 \\
\hline 블일치 & 복구붕일치 & 2 & 0.68 \\
\hline 만족 & 복구만족 & 2 & 0.95 \\
\hline
\end{tabular}

<표2> 탐색적요인분석 결과(실혐1)

\begin{tabular}{|c|c|c|c|c|}
\hline 구성개념 & 문항 & 요인1 & 요인2 & 요인3 \\
\hline 복구기대 & EX1 & 0.887 & & \\
\hline 지각된 & EX2 & 0.890 & & \\
복구성과 & PE2 & & 0.938 & \\
\hline 복구불일치 & DI1 & & 0.919 & \\
& DI3 & & & 0.896 \\
\hline \multirow{2}{*}{ 복구만족 } & SA2 & & & 0.417 \\
\hline
\end{tabular}

<표3> 탐색적요인분석 결과(실헙2)

\begin{tabular}{|c|c|c|c|c|c|c|c|c|}
\hline $\begin{array}{l}\text { 구성 } \\
\text { 개념 }\end{array}$ & 문항 & 요인1 & 요인2 & 요인3 & 요인9 & 요인 10 & 요인11 & 요인 12 \\
\hline 안정성 & $\begin{array}{l}\text { ST1 } \\
\text { ST2 }\end{array}$ & $\begin{array}{l}0.90 \\
0.91\end{array}$ & & & & & & \\
\hline 풍제성 & $\begin{array}{l}\mathrm{CO} 1 \\
\mathrm{CO} 2\end{array}$ & & $\begin{array}{l}0.91 \\
0.92\end{array}$ & & & & & \\
\hline 블형 평성 & $\begin{array}{l}\mathbb{N} 1 \\
\mathbb{N} 2 \\
\mathbb{N} 3\end{array}$ & & & $\begin{array}{l}0.75 \\
0.77 \\
0.78\end{array}$ & & & & \\
\hline 분배적정당성 & $\begin{array}{l}\text { DJ2 } \\
\text { DJ44 }\end{array}$ & & & & $\begin{array}{l}0.76 \\
0.86\end{array}$ & & & \\
\hline 절차적정당성 & $\begin{array}{l}\text { PJ1 } \\
\text { PJ2 } \\
\text { PJ3 }\end{array}$ & & & & & $\begin{array}{l}0.69 \\
0.69 \\
0.81\end{array}$ & & \\
\hline 상호작용적정당성 & $\begin{array}{l}\text { IJ2 } \\
\text { IJ4 } \\
\text { IJ5 }\end{array}$ & & & & & & $\begin{array}{l}0.83 \\
0.86 \\
0.79\end{array}$ & \\
\hline 복구만족 & $\begin{array}{l}\mathrm{SA2} \\
\mathrm{SA3}\end{array}$ & & & & & & & $\begin{array}{l}0.76 \\
0.76\end{array}$ \\
\hline
\end{tabular}


구성개념들간에 LISREL8.30(Jorreskog and Sörbom 1993)에 의한 확인적 요인분석을 봉해 구한 $\varphi$ 매트릭스률 사용하여 판별타당성을 평가하였다. 분석결과 $\varphi$ 계수의 신뢰구간(두 잠재변수간의 상관관계 $\pm 2 \times$ 표준오차)이 실헙1과 실헙2에서 모든 구성개념들간의 관계에 있어서 1.0 미만의 크기를 나타넘으로써 판별타당성이 확보되었다(Anderson 1987). 또한 지각된 복구성과와 복구만족간의 상관관계는 0.87 로서 매우 높기는 하나, $\varphi$ 계수의 신뢰구간이 1.0 미만으로서 두 개념은 동일한 개념으로 볼 수 없기 때문에 분석에 사용하기로 하였다.

<표4> 구성개념간 상관관계 및 표준오차(실협1)

\begin{tabular}{|c|c|c|c|c|}
\hline 구성개념 & 복구기대 & 지각된 복구성 과 & 복구볼일치 & 복구만족 \\
\hline 복구기대 & 1.00 & & & \\
\hline 지각된 복구성과 & $-0.04(0.10)$ & 1.00 & & \\
\hline 복구불일치 & $-0.48(0.10)$ & $0.77(0.06)$ & 1.00 & \\
\hline 복구만족 & $-0.10(0.10)$ & $0.87(0.02)$ & $0.81(0.06)$ & 1.00 \\
\hline
\end{tabular}

<표5> 구성개념간 상관관계 및 표준오차(실헙2)

\begin{tabular}{|c|c|c|c|c|c|c|c|c|}
\hline 구성개넘 & 원인의 위치 & 뽕제성 & 안정성 & 발형평성 & $\begin{array}{l}\text { 분배적 } \\
\text { 정당성 }\end{array}$ & $\begin{array}{l}\text { 절차젹 } \\
\text { 정당성 }\end{array}$ & $\begin{array}{c}\text { 상호작웅젹 } \\
\text { 정당성 }\end{array}$ & 복구 만족 \\
\hline 원인의 위치 & 1.00 & & & & & & & \\
\hline 통재성 & $\begin{array}{c}0.13 \\
(0.08)\end{array}$ & 1.00 & & & & & & \\
\hline 안정성 & $\begin{array}{c}-0.04 \\
(0.08)\end{array}$ & $\begin{array}{c}0.41 \\
(0.07)\end{array}$ & 1.00 & & & & & \\
\hline 블형평성 & $\begin{array}{c}0.33 \\
(0.08)\end{array}$ & $\begin{array}{c}0.48 \\
(0.07)\end{array}$ & $\begin{array}{c}0.50 \\
(0.07)\end{array}$ & 1.00 & & & & \\
\hline 분배적정 당성 & $\begin{array}{l}-0.22 \\
(0.08)\end{array}$ & $\begin{array}{c}0.03 \\
(0.09)\end{array}$ & $\begin{array}{c}-0.18 \\
(0.09)\end{array}$ & $\begin{array}{c}-0.22 \\
(0.10)\end{array}$ & 1.00 & & & \\
\hline 걸차적 정 당성 & $\begin{array}{l}-0.10 \\
(0.08\end{array}$ & $\begin{array}{c}0.18 \\
(0.08)\end{array}$ & $\begin{array}{l}-0.07 \\
(0.08)\end{array}$ & $\begin{array}{l}-0.05 \\
(0.09)\end{array}$ & $\begin{array}{c}0.66 \\
(0.06)\end{array}$ & 1.00 & & \\
\hline 상호적정당성 & $\begin{array}{c}-0.19 \\
(0.07)\end{array}$ & $\begin{array}{c}0.07 \\
(0.08)\end{array}$ & $\begin{array}{c}-0.05 \\
(0.08)\end{array}$ & $\begin{array}{c}-0.11 \\
(0.09)\end{array}$ & $\begin{array}{c}0.59 \\
(0.06)\end{array}$ & $\begin{array}{c}0.78 \\
(0.04)\end{array}$ & 1.00 & \\
\hline 복구만족 & $\begin{array}{c}-0.15 \\
(0.07)\end{array}$ & $\begin{array}{c}0.07 \\
(0.08)\end{array}$ & $\begin{array}{c}-0.02 \\
(0.08)\end{array}$ & $\begin{array}{c}-0.03 \\
(0.09)\end{array}$ & $\begin{array}{c}0.81 \\
(0.05)\end{array}$ & $\begin{array}{c}0.79 \\
(0.04)\end{array}$ & $\begin{array}{c}0.72 \\
(0.04)\end{array}$ & 1.00 \\
\hline
\end{tabular}

\subsection{2. 분석 결과}

(1) 지각된 정당성이 복구만족에 미치는 영향(가설 $1,2,3)$

가설 $1,2,3$ 은 각각 분배적 정당성, 절차적 정당성 및 상호작용적 정당성 지각이 복구만족에 긍정적으로 영향을 미친다는 것이다. 실제 서비스 실패/복구 정황에서 3 가지 차원의 정당성이 동시에 복구만족에 영향울 미칠 것으로 예상되어 복구만족을 종속변수로, 그리고 분배적 정당성, 절차적 정당성 및 상호작용적 정당성을 독립변수로 하여 다중 회귀분석을 
실시하였다. 분석결과 분배적 정당성, 절차적 정당성 및 상호작용적 정당성 모두 복구만족의 크기에 매우 유의적으로 영향을 미치는 것으로 나타났다. 특이한 점은 지각된 정당성중 분배적 정당성의 영향력이 가장 큰 것으로 나타났다. 이는 서비스 실패상황에서 고객의 복구만족에 영향을 미치는 정당성 요인 중에서 유형적인 보상이 무엇보다도 중요함을 시사한다.

<표6> 지각된 정당성이 복구만족에 미치는 영향

\begin{tabular}{|c|c|c|c|c|}
\hline 종속변수 & \multicolumn{4}{|c|}{ 복구만족 } \\
\hline 독립변수 & 비표준화 계수 & 표준화계수 & t该 & 유의도 \\
\hline 분배적 정당성 & 0.378 & 0.384 & 7.473 & .000 \\
\hline 절차적 정당성 & 0.331 & 0.308 & 4.921 & .000 \\
\hline 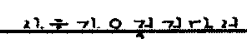 & 0.253 & 0.265 & 4.307 & .000 \\
\hline $\begin{array}{l}\mathbf{R}^{2} \\
\mathrm{~F} \text { 값 }\end{array}$ & \multicolumn{4}{|c|}{$\begin{array}{r}0.646 \\
115.114(\mathrm{p}<\end{array}$} \\
\hline
\end{tabular}

(2) 퀴인적 추론결과가 불형평성 지각에 미치는 영향(가설4)

가설4는 Weiner(1980)의 귀인적 추론의 3가지 차원에 따라 서비스 실패에 대한 고객의 귀인적 추론결과가 불형평성 지각정도에 미치는 영향에 관한 것이다. 본 가설의 검중은 서비스 실패의 원인의 위치(가설4-1), 원인의 안정성(가설4-2) 및 원인에 대한 통제가능성(가설4-3) 이 지각된 불형평성의 크기에 영향을 미치는 정도를 예측하는 것으로서 이러한 3 가지 차원을 독립변수로, 지각된 불형평성의 크기를 종속변수로 하여 다중회귀분석을 실시하였다. 분석결과 귀인적 추론결과가 불형평성 지각정도에 미치는 영향에 관한 가설4는 매우 유의적인 것으로 나타넜다. 특히 원인의 안정성 지각이 가장 큰 요인으로 나타넜는 데, 이는 고객이 서비스 제품에 있어서 장기적인 관계를 보다 중시하기 때문인 것으로 추측된다.

<표7> 귀인적 추론결과가 불형평성 지각에 미치는 영향

\begin{tabular}{|c|c|c|c|c|}
\hline 종속변수 & \multicolumn{4}{|c|}{ 불형평성의 크기 } \\
\hline 독립변수 & 비표준화 계수 & 표준화계수 & t값 & 유의도 \\
\hline 외적귀인정도 & 0.260 & 0.257 & 4.190 & .000 \\
통제가능성 & 0.259 & 0.218 & 3.298 & .001 \\
에걱 서 & 0.430 & 0.351 & 5.337 & .000 \\
\hline $\mathrm{R}^{2}$ & \multicolumn{4}{|c|}{0.303} \\
$\mathrm{~F}$ 값 & \multicolumn{5}{|c|}{$27.413(\mathrm{p}<0.000)$} \\
\hline
\end{tabular}

(3) 지각된 불형평성이 분배적 정당성 지각에 미치는 영향(가설5)

가설5는 서비스 실패 정황에서 지각된 불형평성의 크기가 분배적 정당성 지각에 미치는 영향에 관한 것이다. 단순회귀분석결과 지각된 불형평성의 크기가 지각된 분배적 정당성의 크기에 유의적인 영향을 미치는 것으로 나타났다 $(p<0.05)$. 즉 서비스 실패에 대한 귀인적 
지각결과로 인한 불형평성 지각의 정도가 클수록 서비스 복구에 따른 분배적 정당성 지각에 부정적인 영향을 미치는 것으로 나타났다. 다만 회거계수값의 크기가 작고(-0.122), $\mathbf{R}^{2}$ 값 또한 매우 작아(0.024) 귀인적 추론에 따른 지각된 불형평성이 분배적 정당성에 미치는 영향은 다소 한계적으로 유의한 것으로 나타났다. 이는 고객의 입장에서 서비스 실패의 원인에 대한 추론과 서비스 복구노력에 대한 평가가 동일 접점에서 이루어지기는 하나 동일한 평가대상으로 취급하지는 않을 것이라는 추측을 가져온다. 향후 보다 면밀한 분석이 필요하다.

<표8> 불형평성 지각정도가 분배적 정당성 지각에 미치는 영향

\begin{tabular}{|c|c|c|c|c|}
\hline 종속변수 & \multicolumn{4}{|c|}{ 분배적 정 당성 } \\
\hline 독립변수 & 비표준화 계수 & 표준화계수 & t값 & 유의도 \\
\hline 불형평성 & -0.122 & -0.156 & -2.186 & 0.030 \\
\hline$R^{2}$ & \multicolumn{4}{|c|}{0.024} \\
F 값 & \multicolumn{5}{|c|}{$4.781(\mathrm{p}<0.05)$} \\
\hline
\end{tabular}

(4) 서비스 복구기대 맟 지각된 복구성과가 복구불일치 및 복구만족에 미치는 영향

(가설 $6,7,8,9,10)$

가설 6,7 은 서비스 복구기대가 복구불일치 및 복구만족수준에, 가설 8,9 는 지각된 복구성과 가 복구불일치 및 복구만족수준에, 그리고 가설 10 은 복구불일치가 복구만족수준에 영향을 미칠 것이라는 내용이다. 이에 대한 분석은 LISREL8.30을 이용하여 모형의 적합도를 확인하 고 동시에 모수도 추정하였다. 모수 추정법은 최우추정법을 이용하였다.

모형의 전반적인 적합도 측면에서 $\chi^{2}$ 값이 $9.24(\mathrm{p}=0.82)$ 로 나오고 GFI, AGFI 및 RMR이 각각 $0.99,0.96,0.078$ 올 보여 본 연구에서 제시한 기대불일치모형의 적합도는 매우 높은 것으로 나타났다. 따라서 서비스 실패/복구정황에 있어서 복구에 따른 고객만족은 기대불일치 모형을 통해서 설명이 가능하다는 것을 알 수 있다.

한편 경로간의 계수를 살펴보면 먼저 복구기대가 복구불일치에 미치는 영향은 $-0.45(t$ 값 -2.97)로 나타나 복구기대는 가설6과 부합하게 복구불일치에 유의적으로 부정적인 영향을 미치는 것으로 나타넜다. 또한 복구기대가 만족에 미치는 영향온 0.15 (t값 1.01)로 유의적이지 못한 것으로 나타나 가설7은 기각되었다. 이는 기대가 불일치와 함께 가법적으로 만족에 영향을 미친다고 주장한 Oliver(1980)의 주장과 상이한 결과라고 할 수 있다. 따라서 복구기대는 복구만족에 직접적인 영향을 미치지 못하며, 다만 복구불일치를 통하여 복구만족에 간접적인 영향만을 미치는 것으로 나타넜다. 또한 지각된 복구성과가 복구불일치에 미치는 영향은 $0.76(\mathrm{t}$ 값 3.60$)$ 로 나타나 복구불일치에 매우 큰 영향올 미치는 것으로 나타나 가설 8 이 강하게 지지되었다. 한편 지각된 복구성과가 복구만족에 미치는 영향은 0.49(t)ㅏㅏㅄ 2.69)로 지각된 복구성과는 복구만족에도 상당히 큰 영향을 미치는 것으로 나타넜다. 이에 따라 가설 9도 지지되었다. 한편 복구불일치가 복구만족에 미치는 영향은

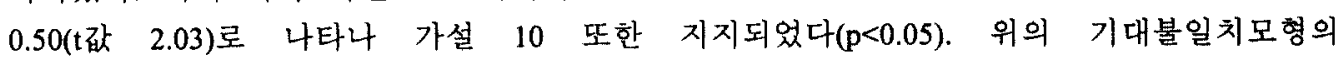
검증결과를 요약하면 다음과 같다 
<표9> 기대불일치관련 가설검중 요약

\begin{tabular}{|c|c|c|c|c|c|c|c|c|}
\hline \multicolumn{3}{|c|}{ 가설경로 및 방향 } & 경로계수 & \multirow{2}{*}{ 표준오차 } & t값 & 유의도 & 지지여부 \\
\hline 가설 & from & to & 부호 & & & & \\
H6 & 기대 & 불일치 & - & -0.45 & 0.15 & -2.97 & $\mathrm{p}<0.01$ & 지지 \\
\hline H7 & 기대 & 만족 & + & 0.15 & 0.15 & 1.01 & $\mathrm{p}>0.10$ & 기각 \\
\hline H8 & 성과 & 불일치 & + & 0.76 & 0.21 & 3.60 & $\mathrm{p}<0.01$ & 지지 \\
\hline H9 & 성과 & 만족 & + & 0.49 & 0.18 & 2.69 & $\mathrm{p}<0.01$ & 지지 \\
\hline H10 & 불일치 & 만족 & + & 0.50 & 0.25 & 2.03 & $\mathrm{p}<0.05$ & 지지 \\
\hline
\end{tabular}

<그립3> 기대불일치모형 분석결과

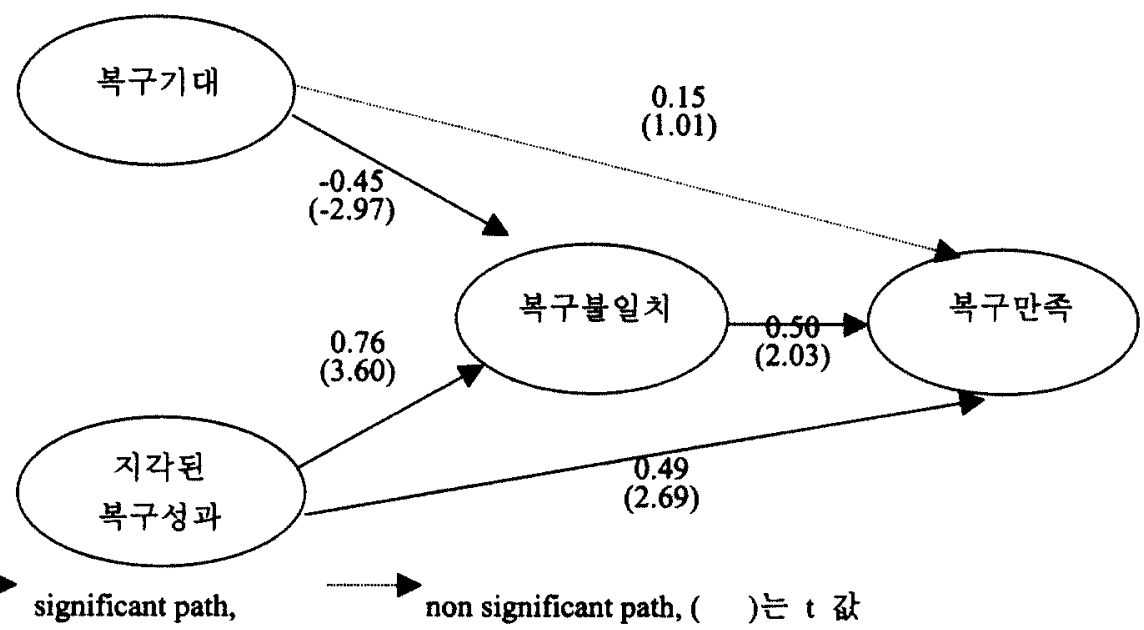

\subsection{3. 정당성 모형과 기대불일치 모형의 비교}

(1) 정당성모형과 기대불일치모형의 설명력 비교

서비스 복구접점에 대한 모형의 설명력율 비교하기 위하여 기대불일치 모형과 정당성 모형간의 적합도를 추가적으로 비교 분석하였다. 첫째 다중회귀분석을 이용하여 결정계수를 비교했으며, 둘째 LISREL8.30을 이용하여 적합도를 비교하였다. 먼저 다중희귀분석에 의한 설명력의 비교 결과는 다음 표와 같다.

<표10> 기대불일치모형과 정당성 모형의 설명력 비교(다중회귀분석)

\begin{tabular}{|c|c|c|}
\hline 구분 & 기대블일치모형 & 정당성모형 \\
\hline $\mathrm{R}^{2}$ & 0.715 & 0.646 \\
\hline $\mathrm{F} \mathrm{값(p값)}$ & $119.034(0.000)$ & $115.114(0.000)$ \\
\hline
\end{tabular}

두 모형 모두 $\mathrm{R}^{2}$ 값 및 $\mathrm{F}$ 값이 크게 나타나 설명력이 매우 큰 것으로 나타넜다. 비교결과는 미세하나마 기대불일치 모형이 설명력이 좀 더 나은 것으로 나타녔다. 
다른 한편으로 LISREL8.30을 이용하여 두 모형을 비교하면 다음과 같다.

<표11> 기대블일치모형과 정당성모형의 적합도비교(구조방정식모형)

\begin{tabular}{|c|c|c|c|}
\hline 구분 & 기대뷸일치모형 & 정당성모형 & 차이 \\
\hline $\begin{array}{c}\chi^{2} \\
(\mathrm{p} \text { 값) }\end{array}$ & $\begin{array}{c}9.24 \\
(0.82)\end{array}$ & $\begin{array}{c}32.86 \\
(0.28)\end{array}$ & -23.62 \\
\hline GFI & 0.98 & 0.97 & 0.01 \\
\hline AGFI & 0.96 & 0.94 & 0.02 \\
\hline RMR & 0.079 & 0.063 & 0.016 \\
\hline $\begin{array}{c}\text { standardized } \\
\text { RMR }\end{array}$ & 0.028 & 0.030 & -0.002 \\
\hline AIC & 53.11 & 83.14 & -30.03 \\
\hline CAIC & 140.75 & 193.97 & -53.22 \\
\hline
\end{tabular}

표에 나타난 바와 같이 기대불일치모형 및 정당성 모형 모두 구조방정식모형 분석을 퉁한 전반적인 모형 적합도는 매우 높게 나타넜으며, $\mathrm{AIC}$ 및 $\mathrm{CAIC}$ 등 전반적 지수가 상대적이나마 기대불일치모형의 우위가 나타났다.

서비스 복구접점에서의 고객만족과정에 대한 비교 분석결과 기대불일치 모형과 정당성 모형 모두 설명력이 매우 높은 것으로 나타넜다. 모형의 우열성은 미세하나마 기대불일치모형이 우위에 있는 것으로 나타넜으나 그 차이는 무시할 정도라고 판단된다. 졀과적으로 본 연구에서 두 모형간의 우열은 가리기가 매우 어려우며, 이는 결국 서비스 복구접점에서의 복구만족과정에 대한 설명변수가 다차원적이며, 소비자들의 심리과정이 다양하다는 중거이다. 사실 기대불일치 모형은 비교의 표준이 자신(기대)에게 있는 반면에, 정당성 모형은 비교의 표준이 사희(당위)에 있다고 할 수 있다. 따라서 하나의 현상을 설명하기 위하여 개인적 차원의 기대불일치 모형과 사회적 차원의 정당성 모형 양자가 상호 병렬적으로 적용되는 것으로 생각된다.

(2) 정당성 모형과 기대뷸일치 모형의 계수 비교

모형의 일관된 비교를 위해 표준화된 계수값을 비교하였다. 먼저 기대불일치모형에 있어서는 분석방법에 관계없이 복구기대가 복구만족에 미치는 영향은 비유의적으로 나타났다. 하지만 지각된 복구성과와 복구불일치가 복구만족에 미치는 영향에 있어서는 분석방법에 따라 차이가 있었다. 즉 LISREL8.30에 의한 분석결과는 지각된 복구성과와 복구불일치가 복구만족에 미치는 영향은 거의 동일하게(각각 0.49 및 0.50 ) 나타난 반면에 다중회귀분석에 의한 분석결과는 지각된 복구성과가 미치는 영향(0.691)이 복구불일치가 미치는 영향(0.221)보다 횔신 크게 나타났다. 이러한 결과는 다중회귀분석은 지각된 복구성과와 복구불일치가 독립변수로서 종속변수인 복구만족에 독립적으로 영향을 미친다고 가정하는 반면에. 구조방정식모형에서는 복구불일치가 복구기대와 지각된 복구성과가 복구만족에 미치는 영향을 매개하는 내생변수이기 때문인 것으로 판단된다.

다른 한편으로 정당성모형에 있어서는 다중희귀분석울 실시하는 경우에 복구만족에 유의적인 영향올 미쳤던 상호작용적 정당성이 구조방정식모형에서는 비유의적인 것으로 나타났다. 또한 분배적 정당성의 효과도 다중회귀분석에 의한 표준화된 회귀계수값보다 
구조방정식모형에서 휠씬 크게(각각 $0.384,0.50$ ) 나타났다. 기존의 연구문헌에 의하면 상호작용적 정당성 지각은 복구만족에 긍정적인 영향을 미친다는 것이 대체로 일치된 발견이다(Smith et al. 1999; Goodwin and Ross 1992; McCollough et al. 2000). 상호작용적 정당성이 복구만족에 유의적인 영향을 미치지 못하는 결과가 나온 것에 대한 추가적인 연구가 필요하다. 또한 분배적정당성의 효과가 매우 크게 나타난 것은 상호작용적정당성의 효과를 흡수한 결과로 보인다.

<표12> 다중회귀분석에 의한 기대불일치 및 정당성 모형의 희귀계수

\begin{tabular}{|c|c|c|c|c|}
\hline 종속변수 & \multicolumn{4}{|c|}{ 복구만족 } \\
\hline 독립변수 & 비표준화 계수 & 표준화계수 & $\mathrm{t}$ 값 & 유의도 \\
\hline 복구기대 & 0.018 & 0.016 & 0.320 & .749 \\
지각된 복구성과 & 0.516 & 0.691 & 11.646 & .000 \\
복구불일치 & 0.233 & 0.221 & 3.485 & .001 \\
\hline \hline 중속변수 & \multicolumn{5}{|c|}{ 복구만족 } \\
\hline 독립변수 & 비표준화 계수 & 표준화계수 & t값 & 유의도 \\
\hline 분배적 정당성 & 0.378 & 0.384 & 7.473 & .000 \\
절차적 정당성 & 0.331 & 0.308 & 4.921 & .000 \\
상호작용적정당성 & 0.253 & 0.265 & 4.307 & .000 \\
\hline
\end{tabular}

<표13> 구조방정식모형에 의한 기대불일치 및 정당성 모형의 경로계수

\begin{tabular}{|c|c|c|c|c|c|}
\hline from & to & 경로계수 & 표준오차 & t값 & 유의도 \\
\hline 복구기대 & \multirow{3}{*}{ 복구만족 } & 0.15 & 0.15 & 1.01 & $p>0.10$ \\
\hline 지각된 복구성과 & & 0.49 & 0.18 & 2.69 & $p<0.01$ \\
\hline 복구불일치 & & 0.50 & 0.25 & 2.03 & $p<0.05$ \\
\hline from & to & 경로계수 & 표준오차 & 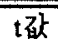 & 유의도 \\
\hline 분배적 정당성 & \multirow{3}{*}{ 복구만족 } & 0.50 & 0.11 & 4.36 & $\mathrm{p}<0.10$ \\
\hline 절차적 정당성 & & 0.35 & 0.12 & 2.96 & $\mathrm{p}<0.01$ \\
\hline 상호작용적정 당성 & & 0.14 & 0.09 & 1.57 & $p>0.10$ \\
\hline
\end{tabular}

\section{5. 결 론}

\section{1 연구의 요약}

본 연구는 서비스 실패/복구정황에 대한 고객의 평가과정을 보다 포괄적으로 설명하고자 정당성 모형과 기대불일치모형을 동시에 연구하였다. 또한 거인이론의 결과를 이용하여 고객만족과정을 보다 심충적으로 분석하고자 하였다. 이를 실증분석하기 위해서 2 개의 실헙올 동시에 실시하였으며, 수집된 자료는 정당성 접근모형은 SPSS10.0에 의한 다중회귀분석 및 단순회귀분석을 그리고 기대불일치 접근모형은 LISREL 8.30 에 의한 구조방정식모형을 통해 이를 분석하였다. 전체적인 실중분석결과 본 연구에서 제시하고 
있는 가설중 복구기대가 복구만족에 미치는 영향에 관한 가설을 제외한 나머지 모든 가설이 통계적으로 유의한 것으로 입중되었다.

먼저 회사의 복구노력에 대한 고객의 지각이 복구기대와 서로 일치되는 정도에 따라 서비스 접점에서의 복구만족이 이루어지는 것으로 나타났다. 또한 지각된 복구성과는 복구만족에 직접적인 영향을 미칠 뿐만 아니라 복구불일치룔 통하여 간접적으로 복구만족에 영향을 미치는 것으로 나타넜다. 또한 회사의 복구노력은 분배적 정당성, 절차적 정당성 및 상호작용적 정당성올 지각하게 함으로써 서비스 접점에서 복구만족을 유도하는 것으로 밝혀졌다.

또한 서비스 실패에 대한 고객의 귀인적 추론졀과가 서비스 접점에서의 복구만족과정에 영향을 미쳤다. 실중분석결과 원인의 위치가 희사에 있다고 추론할수록, 회사가 원인에 대해 통제가능하다고 추론할수록 그리고 원인이 미래에도 지속될 것이라고 추론할수록 서비스 접점에서 불형평성의 지각정도는 커지는 것으로 나타났다. 또한 이러한 불형평성은 부분적으로 회사의 복구노력에 대해 고객이 지각하는 분배적정당성의 지각에 부정적인 영향을 미침으로써 복구만족에 간접적으로 부정적인 영향력을 미치는 것으로 나타났다. 이와같이 서비스 실패/복구 정황에서의 고객만족과정이 기대불일치이론, 정당성이론 및 귀인이론에 의하여 다차원적으로 설명되었다.

또한 기대불일치모형과 정당성모형이 서비스 실패/복구정황에 대해 설명하는 정도률 비교분석한 결과 두 모형 모두 서비스 접점에서의 고객만족과정에 대한 설명력이 매우 높았으며, 상대적이나마 기대불일치모형이 우수하였다.

\section{2. 시사점 및 미래 연구방향}

\subsection{1. 연구의 시사점}

연구결과에 의하면 고객의 만족과정에 대한 설명은 기대불일치이론, 정당성 이론 및 퀴인이론 등 다양한 차원에서 설명이 가능하였다. 이러한 연구결과는 소비자의 사고의 다양성 내지 심리적 복잡성을 반영한다.

사실 기대불일치 모형은 비교의 표준이 자신(의 기대)에게 있는 반면에, 정당성 모형은 비교의 표준이 사희적 교환(당위)에 있다고 할 수 있다. 서비스 접점에서도 이러한 개인적 및 사회적 차원의 인간사고는 펄연적이다. 따라서 서비스 접점에 대한 평가에 있어 개인기준의 평가와 사회기준의 평가가 공존한다. 이러한 개인적 차원의 평가모형이 기대불일치 모형이고, 사희적 차원의 평가모형이 정당성 모형이라고 할 수 있다. 즉 본 연구에서 기대불일치 모형과 정당성 모형 모두가 설명력이 높게 나은 것은 오히려 자연스럽다. 이러한 결과는 합리적 행동이론(Fishbein and Ajzen 1975)에서의 행동에 대한 태도(개인적 요인)와 주관적 규범(사회적 요인)이 동시에 행동에 영향을 미친다는 것과 동일한 맥락이라고 할 수 있다.

또한 기업은 서비스 실패 후에 복구노력을 하는데 있어 고객만족의 극대화를 가져오기 위해서 서비스 실패시 각종 보상제도의 개발, 복구절차의 간소화 및 종업원의 혼련을 퉁한 고객응대방법의 향상 등을 통해 정당성 지각의 향상을 도모해야 할 것이다, 특히 분배적 정당성 지각이 여타 정당성 지각보다 고객만족효과가 큰 것으로 나타난 것은 서비스 실패에 대한 다양한 보상시스템이 서비스 기업에게 필수적이라는 것을 시사한다.

한편 귀인적 관점에서 기업들은 종업원들로 하여금 서비스 실패가 발생하지 않도록 
충분한 교육이 취해져야 할 것이며, 또한 고객으로 하여금 회사가 노력했음에도 볼구하고 서비스 실패가 발생했다고 인식시키고 또한 실패원인 또한 일시적이라는 것을 주지시키기 위한 종업원들의 고객웅대요령에 대한 교욕이 중요하다고 하겠다.

5.2.2. 연구의 한계 및 미래 연구방향

본 연구는 서비스 실패/복구 정황에 대한 다차원적 접근방법의 시도 및 이에 대한 실중분석에도 블구하고 여러 가지 한계점을 가지고 있다.

첫째 본 연구는 정당성이론, 기대불일치이론 및 귀인이론 둥의 다차원적 접근방법을 통해 서비스 실패/복구정황에서의 고객의 만족과정을 설명하고 있으나, 이러한 접근방법들이 분석방법의 한계 둥으로 단지 개별적 분석 및 비교분석만을 실시하고 단일한 모형으로 퉁합되지 못함으로써 하나의 현상에 대한 일관되면서도 포괄적인 설명이 미홉하다고 할 수 있다. 따라서 서비스 실패/복구정황에 있어 고객만족과정에 대한 개별적인 접근방법들을 통합하기 위한 자료의 수집방법, 분석 방법 둥에 대한 보다 면밀한 연구가 펄요할 것이다.

둘째 실중을 위한 분석자료의 수집이 가상의 시나리오에 의한 웅답자의 설문으로만 이루어져 있음으로서 실제 거래에서의 서비스 실패경헙에 기초한 실제적인 고객지각의 측정이 이루어지지 못하여 분석결과의 실제성이 담보되지 못하는 위험이 있다. 자료수집방법에 있어 중요사건기법의 도입도 필요하다고 생각한다.

셋째 본 연구는 측정변수의 타당성 분석에 있어 일부변수가 공퉁요인에 적재됨으로써 구성개넘들의 개녑타당성 확보에 다소 미흡한 요소가 있었다. 이는 예비조사를 통한 보다 면밀한 분석을 퉁해 제거할 수 있는 부분으로서 설문지 작성에 있어서 주의가 요망되는 부분이다.

넷째 본 연구는 정당성, 퀴인, 기대불일치이론 등의 기본개념간의 관계만을 분석하고, 서비스 접점에서의 여러 가지 가능한 상황적요인 및 개인적 특성들에 대한 고려가 이루어지지 못함으로써 모형의 실제성 확보에 다소 미홉함이 있었다. 따라서 서비스 산업의 유형, 서비스 접점의 상황적 특성 및 고객의 개인적 튝성을 모형에 통합시키는 방법을 통해 서비스 실패/복구 정황에 있어 고객만족과정에 대한 실제적이면서도 포괄적인 연구모형의 제시가 필요할 것이다.

끝으로 상호작용적 정당성의 지각이 복구만족에 미치는 영향에 있어 분석방법에 따라 통계적 유의성에 차이가 있는 것으로 나타난 이유 및 복구기대가 복구만족에 직접적인 효과를 가진다는 가설이 기각된 이유에 대하여는 추가적인 연구가 필요하다. 


\section{〈참고문헌〉}

곽동성, 김규동(1997), “소비자 만족 형성과정에 영향을 미치는 상황변수에 관한 연구 고관여시 제품 평가 용이성의 개념올 중심으로.," 마케팅연구, 제12권 제1호, 183-206

임종원(1997), 마케텅조사 이렇게, 법문사

Adams, J. Stacy (1965), "Inequity in Social Exchange," in Advances in Experimental Social Psychology, Vol. 2, Leonard Berkowitz, ed. New York: Academic Press, 267-99.

Anderson, Eugene W. and Mary W. Sullivan(1993), "The Antecedents and Consequences of Customer Satisfaction for Firms," Marketing Science, 12(Spring), 125-43

Anderson, James C.(1987),"An Approach for Confirmatory Measurement and Structural Equation Modeling of Organizational Properties," Management Science,33(4), 525-4I

Anderson, Ralph E. (1973), "Consumer Dissatisfaction: The Effect of Disconfirmed Expectancy on Perceived Product Performance," Journal of Marketing Research, 10(November), 21-8

Andreeva, Nellie(1998),"Unsnarling Traffic Jams at U.S. Airports," Business Week, August 10, 84.

Bagozzi, Richard P. (1975), "Marketing as Exchange," Journal of Marketing, 39 (October), 32-39.

Bell, Chip R. and Zemke(1987), "Service Breakdown: The Road to Recovery," Management Review, October, 32-35

Berry, Leonard L. and A. Parasuraman (1991), Marketing Services: Competing Through Quality. New York: The Free Press.

Bies, Robert J. and Joseph S. Moag (1986), "Interactional Justice: Communication Criteria of Fairness," in Research on Negotiation in Organizations, Vol. 1, Roy J. Lewicki, Blair H. Sheppard, and Max H. Bazerman, eds. Greenwich, CT: JAI Press, 43-55.

Bies, Robert J. and Debra L. Shapiro (1987), "Interactional Faimess Judgments: The Influence of Causal Accounts," Social Justice Research, 1 (2), 199-218.

Bitner, Mary Jo (1990), "Evaluating Service Encounters: The Effects of Physical Surroundings and Employee Responses," Journal of Marketing, 54 (April), 69-82.

Bitner, Mary Jo, Bernard H. Booms, and Mary Stanfield Tetreault (1990), "The Service Encounter: Diagnosing Favorable and Unfavorable Incidents," Journal of Marketing, 54 (January), 71-84.

Bitner, Mary Jo, Bernard H. Booms, and Lois A. Mohr(1994), "Critical Service Encounters: The Employee's Viewpoint," Journal of Marketing, 58(October), 95-106

Blodgett, J. G. and S. S. Tax(1993),"The Effects of Distributive and Interactional Justice on Complainants' Repatronage Intentions and Negative Word-of-Mouth Intentions," Journal of Consumer Satisfaction, Dissatisfaction and Complaining Behavior, 6:100-110.

Blodgett, Jeffrey G., Donald H. Granbois, and Rockney G. Walters (1993), "The Effects of Perceived Justice on Complainants' Negative Word-of-Mouth Behavior and Repatronage Intentions," Journal of Retailing, 69 (4), 399-428.

Blodgett, Jeffrey G., Donna J. Hill, and Stephen S. Tax (1997), "The Effects of Distributive, Procedural, and Interactional Justice on Postcomplaint Behavior," Journal of Retailing, 73 (2), 185-210.

Churchill, Gilbert A. and Carol Surprenant (1982), "An Investigation into the Determinants of Customer Satisfaction," Journal of Marketing Research, 19(November), 491-504

Clemmer, E. C.(1993),"An Investigation into the Relationships of Justice and Customer Satisfaction with Services," In R. Cropanzano(ed), Justice in the Workplace: Approaching Fairness in Human Resources Management. Hillsdale, NJ:Erlbaum

Clemmer, Elizabeth C. and Benjamin Schneider(1996), "Fair Service," in Advances in Services Marketing and Management, Vol. 5, Teresa A. Swartz, David E. Bowen, and Stephen W. Brown, eds. 
Greenwich, CT: JAI Press, 109-26.

David, M.(1998),"Organizational Response to Consumer Complaints and Their Impact on Post-Complaint Consumer Behavior," Texas A\&M univ.

Deutsch, Morton (1975), "Equity, Equality, and Need: What Determines Which Value Will Be Used as the Basis of Distributive Justice?" Journal of Social Issues, 31 (3), 137-49.

Etzel, Michael J. and Bernard I. Silverman (1981), "A Managerial Perspective on Directions for Retail Customer Dissatisfaction Research:' Journal of Retailing, 57 (Fall), 124-36.

Fishbein, Martin and Icek Ajzen(1975), Belief, Attitude, Intention and Behavior: An Introduction to Theory and Research, Reading, MA:Addison Wesley

Folkes, Valerie S. (1984), "Consumer Reactions to Product Failure: An Attributional Approach," Journal of Consumer Research, 10 (March), 398-09.

Folkes, Valerie S., Susan Koletsky, and John L. Graham (1987), "A Field Study of Causal Inferences and Consumer Reaction: The View from the Airport," Journal of Consumer Research, 13 (March), 534-39.

Gilly, M. C.(1987), "Postcomplaint Processes : From Organizational Response to Repurchase Behavior", Journal of Consumer Affairs, Winter, pp. 293-313

Gilly, M. C. and Betsy D. Gelb (1982), "Post-Purchase Consumer Processes and the Complaining Consumer," Journal of Consumer Research, 9 (December), 323-28.

Goodwin, Cathy and Ivan Ross (1992), "Consumer Responses to Service Failures: Influences of Procedural and Interactional Fairness Perceptions," Journal of Business Research, 25 (2), 149-63.

Greenberg, J. and S. Ornstein(1983),"High Status Job Title as Compensation for Underpayment: A Test of Equity Theory", Journal of Applied Psychology, 68, pp. 129-133

Grönroos, Christian (1988), "Service Quality: The Six Criteria of Good Perceived Service Quality," Review of Business, 9 (Winter), 10-13.

Hart, Christopher W., James L. Heskett, and W. Earl Sasser Jr. (1990), "The Profitable Art of Service Recovery," Harvard Business Review, 68 (July/August), 148-56.

Heskett, J. L., W. E. Sasser and C. W. L. Hart(1990), Service Breakthroughs: Changing the Rules of the Game, New York:Free Press.

Johnston, Robert (1995), "Service Failure and Recovery: Impact, Attributes and Process," in Advances in Services Marketing and Management, Vol. 4, Teresa A. Swartz, David E. Bowen, and Stephen W. Brown, eds. Greenwich, CT: JAI Press, 211-28.

Jöreskog, Karl G. and Dag Sörbom (1993), LISREL 8: Structural Equation Modeling with the SIMPLIS Command Language. Chicago: Scientific Software International.

Kelley, Scott W. and Mark A. Davis (1994), "Antecedents to Customer Expectations for Service Recovery," Journal of the Academy of Marketing Science, 22 (1), 52-61.

Lovelock, C. H.(1991), Services Marketing, 2nd Ed., Prentice-Hall, Englewood Cliffs, NJ

McCollough, Michael A., Leonard L. Berry, and Manjit S. Yadav(2000),"An Empirical Investigation of Customer Satisfaction after Service Failure and Recovery," Journal of Service Research 2(November), 121-137

Mohr, L. A.(1991), Social Episodes and Consumer Behavior: The Role of Employee Effort in Satisfaction with Services, unpublished doctoral dissertation, Arizona State University.

Nunally, Jum C.(1978), Psychometric Theory, 2 nd ed., New York : McGraw-hill Book Company

Oliver, Richard L. (1980), "A Cognitive Model of the Antecedents and Consequences of Satisfaction Decisions," Journal of Marketing Research, 17 (September), 46-49.

Oliver, Richard L. and William O. Bearden (1985), "Disconfirmation Processes and Consumer Evaluations in Product Usage," Journal of Business Research, 13 (June), 235-46. 
Oliver, Richard L. and John E. Swan (1989a), "Consumer Perceptions of Interpersonal Equity and Satisfaction in Transactions: A Field Survey Approach," Journal of Marketing, 53 (April), 21-35.

Oliver, Richard L. and John E. Swan (1989b), "Equity and Disconfirmation Perceptions as Influences on Merchant and Product Satisfaction," Journal of Consumer Research, 16 (December), 372-83.

Oliver Richard L. and Wayne S. DeSarbo(1988),"Response Determinants in Satisfaction Judgements", Journal of Consumer Research, 14(March), 495-507

Olshavsky, Richard W. and John A. Miller(1972),"Consumer Expectation, Product Performance and Perceived Product Quality," Journal of Marketing Research, 9(February), 19-21

Rust, Roland T. and Richard Metters (1996), "Mathematical Models of Service," European Journal of Operational Research, 91 (June), 427-39.

Smith, A., Bolton, R. N. and Wagner, J.(1999),"A Model of Customer Satisfaction with Service Encounters Involving Failure and Recovery," Journal of Marketing Research 36(August), 356-372

Spreng, Richard A., Gilbert D. Harreil, and Robert D. Mackoy (1995), "Service Recovery: Impact on Satisfaction and Intentions," Journal of Services Marketing, 9 (I), 15-23.

Swan, John E. and Frederick 1. Terrawick (1981), "Disconfirmation of Expectations and Satisfaction with a Retail Service," Journal of Retailing, 57 (Fall), 49-67.

Tax, Stephen Saul (1993), "The Role of Perceived Justice in Complaint Resolutions: Implications for Services and Relationship Marketing," doctoral dissertation, Arizona State University.

Tax, Stephen S. and Murali Chandrashekaran(1992),"Consumer Decision Making Following a Failed Service Encounter: A Pilot Study," Journal of Consumer Satisfaction, Dissatisfaction, and Complaining Behavior, 5, 55-684

Tax, Stephen Saul, Stephen W. Brown, and Murali Chandrashekaran (1998), "Customer Evaluations of Service Complaint Experiences: Implications for Relationship Marketing," Journal of Marketing, 62 (April), 60-77.

Thibaut, John and Laurens Walker (1975), Procedural Justice: A Psychological Analysis. Hillsdale, NJ: Lawrence Erlbaum Associates.

Tse, David K. and Peter C. Wilton(1988),"Models of Consumer Satisfaction : An Extension," Journal of Marketing Research, 25(May), 201-12

Utne, M. K. and R. Kidd(1980),"Equity and Attribution", in G. Mikula., (ed.), Justice and Social Interaction, New York:Springer-Verlag, pp. 63-94

Weiner, B.(1980), Human Motivation, Holt, Rinehart, and Winston, New York, NY.

Westbrook, Robert A. (1980), "Intrapersonal Affective Influences on Consumer Satisfaction with Products," Journal of Consumer Research, 7 (June), 49-54.

Westbrook, R. A. (1987),"Product/Consumption-Based Affective Response and Postpurchase Processes," Journal of Marketing Research, 14, Aug., 258-270

Zeithaml, Valarie A., Leonard L. Berry, and A. Parasuraman (1993), "Tbe Nature and Determinants of Customer Expectations of Service," Journal of the Academy of Marketing Science, 21 (1), 1-12.

Zeithaml, Valerie A., Leonard L. Berry, and A. Parasuraman (1996), "The Behavioral Consequences of Service Quality," Journal of Marketing, 60 (April), 31-46.

Zeithaml, Valerie A., A. Parasuraman, and Leonard L. Berry(1990), Delivering Quality Service : Balancing Customer Perceptions and Expectations, New York, NY : The Free Press. 